DOI: 10.17707/AgricultForest.64.3.12

\author{
Željko Lakić, Igor Đurđić, Marina Antić ${ }^{1}$
}

\title{
VARIABILITY OF YIELD AND YIELD COMPONENTS OF SELECTED GENOTYPES OF ITALIAN RYEGRASS
}

\section{SUMMARY}

Italian ryegrass (Lolium multiflorim L.) is a short-term grass species that is of great importance for the production of quality fodder on arable land. It is grown in pure sowing or in short-term grass-leguminous mixtures. For the sowing of grasslands in Bosnia and Herzegovina, the significant seed quantities of the Italian ryegrass are used. The aim of this paper is to examine the yield variability and yield components of the progeny of the own selection of Italian ryegrass "BL Vubo" in relation to the four varieties of the Italian ryegrass that are most often used in our area. The research was carried out in the testing field and in the laboratories of the Agricultural Institute of the Republic of Srpska in Banja Luka during 2014 and 2015. These tests include the local selection "BL Vubo" and 4 foreign and local diploid and tetraploid varieties of the Italian ryegrass: Tur, Danergo, Draga and Tetraflorum. During the study, the following properties were monitored: number of generative stems per plant, spike length, number of spikelets per spike and seed yield per plant.

During the two-year study, the highest average number of generative stems per plant was found in the Draga variety $(183,6)$ and the lowest in the Tur variety $(158,2)$. The average length of the Italian ryegrass in the tested genotypes varied from 23,4 cm (Draga) to 29,5 cm (Tetraflorum). The highest average number of spikelets/spike was found in the Tur variety $(27,1)$. When it comes to yield of seeds/plants, the variety Draga (72,4 g) and the local selection "BL Vubo" (68,8 g) were distinguished. The variety had a highly significant influence on all tested properties $(p<0,01)$. For the spike length, it is determined that year had highly significant influence $(p<0,01)$, while for the rest of the examined properties, the effect of the year was significant $(p<0,05)$. The existence of an interaction genotype $\mathrm{x}$ year has not been determined for any property.

Key words: Italian ryegrass, genotype, spike length, spikelets, seed yield.

\section{INTRODUCTION}

Italian ryegrass is one of the most common cultivated short-term grass species. It is a plant species of moderate climates, which best grows on fertile soil

\footnotetext{
${ }^{1}$ Željko Lakić, University of Banja Luka, Faculty of Agriculture and PI Agricultural Institute of Republic of Srpska, Banja Luka BOSNIA AND HERZEGOVINA, Igor Đurđić, (corresponding author: i_djurdjic@yahoo.com), University of East Sarajevo, Faculty of Agriculture, East Sarajevo, BOSNIA AND HERZEGOVINA, Marina Antić, Institute of genetic resources, University of Banja Luka, BOSNIA AND HERZEGOVINA

Notes: The authors declare that they have no conflicts of interest. Authorship Form signed online.
} 
in conditions of sufficient amount of precipitation or with the application of irrigation. It is very important to note that the Italian rye grass starts with vegetation early in the spring, and can grow until late autumn. In the Italian ryegrass we distinguish short-term (one-year) and two-year forms. The length of life of the plants of the Italian ryegrass almost no exceeds longer than two years. On suitable land for cultivation it grows very quickly and is able to push other grass species. The low tolerance of the Italian ryegrass to the cold prevents its spread in colder areas (Redfearn et al., 2002). Tolerance of the Italian ryegrass to the cold varies depending on the genotype. Experimental studies of diploid and tetraploid varieties of the Italian ryegrass showed that the diploid varieties had greater tolerance to cold than tetraploid (Park et al., 1987). Tetraploid varieties are interesting because they give higher yield of green mass, but yields of seeds are lower in relation to diploid. It is noticed that tetraploid ryegrasses has larger seeds than the corresponding values recorded for diploid strains (Simić et al., 2010)

In Bosnia and Herzegovina, there are no recognized domestic varieties of Italian ryegrass. The needs for the seed of this plant species are met by importing and own production of seeds of domesticated varieties of Italian ryegrass. At the annual level, the need for Italian ryegrass seeds in Bosnia and Herzegovina varies considerably, ranging from 18 tonnes to over 50 tonnes.

In the Agricultural Institute of the Republic of Srpska, Banja Luka, the program of creating its own varieties of Italian ryegrass was launched. After many years of work using the method of individual selection and polycross from selected domestic populations of Italian ryegrass from the mountainous region of the Republic of Srpska, a variety was created under the name "BL Vubo" and was introduced to the Commission for the recognition of varieties in Serbia.

The aim of this paper was to examine the variability of yield and seed yield components of the progeny of their own selection of Italian ryegrass "BL Vubo" in relation to the four varieties of the Italian ryegrass that are most often used in our area.

\section{MATERIAL AND METHODS}

The research was carried out in the experimental field and in the laboratories of the Agricultural Institute of the Republic of Srpska in Banja Luka during 2014 and 2015. These tests include the domestic selection "BL Vubo" and 4 foreign and domesticated diploid and tetraploid varieties of the Italian ryegrass: Tur, Danergo, Draga and Tetraflorum. During the examination, each genotype was represented with 52 plants (clone) in the experimental field. Individual plants were sown at the beginning of September 2013 with three seeds each. Each genotype was sown in 4 rows. It was 13 plants per row. The distance between plants in row and between rows was $50 \mathrm{~cm}$. During the examination, harrowing and intertillage was performed. Plants were top dressed early in the spring with $81 \mathrm{~kg} / \mathrm{ha}$ of $\mathrm{N}$ twice during both years of testing. During the study, the following properties were monitored: number of generative stems per plant, 
spike length, number of spikelets per spike and seed yield per plant. After harvest, the crop is top dressed and mowed until the end of the vegetation.

The obtained data were processed by statistical calculation of the mean value and the corresponding measures of variability. The results obtained during these trials were analysed by two factor analysis of variance (ANOVA), and the significance of the difference in mean values was determined by the LSD test.

\section{Soil properties}

\section{RESULTS AND DISCUSSION}

In the experimental field of the Agricultural Institute of the Republic of Srpska, Banja Luka dominated type of soil is valley-brown soil on the alluvial substrate of Vrbas. The soil by mechanical composition belongs to a clay-loam group. The structure of this type of soil in the surface layer is crumbly. The results of the chemical analyses of the arable layer of soil on which the experiment is placed are shown in Table 1.

Table 1 . The results of the chemical analyses of the arable layer of soil

\begin{tabular}{|c|c|c|c|c|c|}
\hline $\begin{array}{c}\text { Depth } \\
(\mathrm{cm})\end{array}$ & $\begin{array}{c}\text { Humus } \\
\%\end{array}$ & $\begin{array}{c}\mathrm{pH} \\
\text { in } \mathrm{H}_{2} \mathrm{O}\end{array}$ & $\begin{array}{c}\mathrm{pH} \\
\text { in } \mathrm{KCl}\end{array}$ & $\begin{array}{c}\mathrm{P}_{2} \mathrm{O}_{5} \\
\mathrm{mg} / 100 \mathrm{~g} \text { of soil }\end{array}$ & $\begin{array}{c}\mathrm{K}_{2} \mathrm{O} \\
\mathrm{mg} / 100 \mathrm{~g} \text { of soil }\end{array}$ \\
\hline $0-30$ & 2,0 & 7,1 & 6,4 & 16,1 & 22,9 \\
\hline
\end{tabular}

In terms of $\mathrm{pH}$, the soil reaction is neutral and, according to the content of humus, it belongs to the land with low humus content (2,0\%). The availability of easily accessible phosphorus is good (16,1 $\mathrm{mg} / 100 \mathrm{~g})$. According to the results of chemical analysis of the arable layer, the availability of easily accessible potassium is good (Tab.1).

Based on the results of chemical analysis of the arable layer of soil, it can be concluded that the land is suitable for cultivating the Italian rye grass.

\section{Meteorological conditions}

For analysing the weather conditions during the performance of the experiment, data of the Hydro meteorological Station in Banja Luka were used (Graphs 1 and 2).

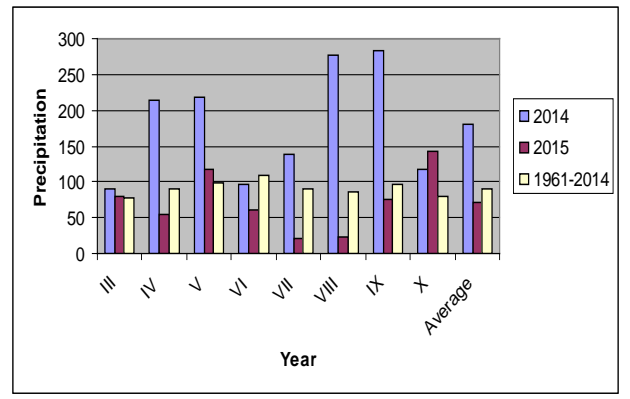

Graph1. Temperature

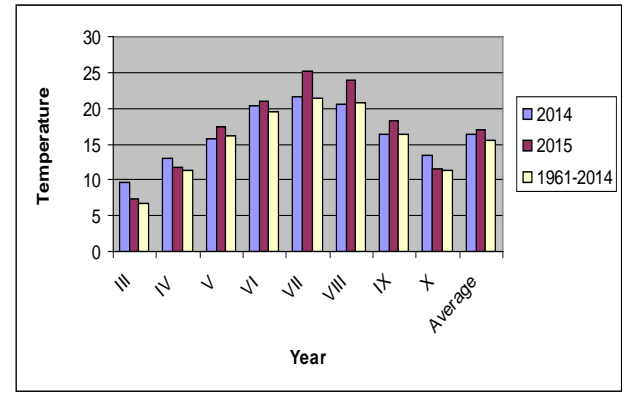

Graph 2. Precipitation 
The average multi-year temperature during the vegetation period (III-X) was $15,4^{\circ} \mathrm{C}$. Total amount of precipitation in the vegetation period (III-X) for the period 1961-2014 was $729,0 \mathrm{l} / \mathrm{m}^{2}$.

The average temperatures for both years of testing during the vegetation period were higher than the multi-year average (1961-2014). In the first year of testing the amount of precipitation during the vegetation period, compared to the multi-year average, was increased for $707,0 \mathrm{l} / \mathrm{m}^{2}$. During the vegetation period 2015 it fell $572,2 \mathrm{l} / \mathrm{m}^{2}$, which is $153,8 \mathrm{l} / \mathrm{m}^{2}$ of precipitation less compared to the multi-year average.

\section{Number of generative stems per plant}

The average number of generative stems/plant is shown by the year of testing in Table 2.

Table 2. Average number of generative stems per plant at the investigated genotypes of the Italian ryegrass

\begin{tabular}{|c|c|c|c|c|c|}
\hline \multirow{3}{*}{ No } & \multirow{3}{*}{\multicolumn{2}{|c|}{ Genotype (A) }} & \multirow{3}{*}{$\begin{array}{l}\mathrm{Ye} \\
2014 \\
\bar{X} \pm S_{X}\end{array}$} & Year (B) & \multirow{3}{*}{$\bar{X} A$} \\
\hline & & & & 2015 & \\
\hline & & & & $\bar{X} \pm S_{x}$ & \\
\hline 1. & \multicolumn{2}{|l|}{ Tur } & $162,8 \pm 20,9$ & $153,5 \pm 19,6$ & 158,2 \\
\hline 2. & \multicolumn{2}{|c|}{ Danergo } & $184,3 \pm 12,2$ & $177,5 \pm 14,0$ & 180,9 \\
\hline 3. & \multicolumn{2}{|c|}{ Draga } & $190,8 \pm 14,0$ & $176,3 \pm 17,2$ & 183,6 \\
\hline 4. & \multicolumn{2}{|c|}{ Tetraflorum } & $168,5 \pm 14,2$ & $161,8 \pm 12,6$ & 165,2 \\
\hline 5. & \multicolumn{2}{|c|}{ BL-Vubo } & $182,3 \pm 14,5$ & $172,0 \pm 19,6$ & 177,2 \\
\hline \multicolumn{3}{|c|}{$\bar{X} B$} & 177,7 & 168,2 & \\
\hline \multicolumn{3}{|c|}{ Basic factors } & A & $\mathrm{B}$ & $\mathrm{AB}$ \\
\hline \multicolumn{3}{|c|}{ Variance analysis- $\mathrm{F}_{\text {calculated }}$} & $5,187^{* *}$ & $4,953^{*}$ & 0,112 \\
\hline \multirow{2}{*}{\multicolumn{2}{|c|}{ LSD }} & 0,05 & 13,8 & 8,8 & 19,6 \\
\hline & & 0,01 & 18,7 & 11,8 & 26,4 \\
\hline
\end{tabular}

After two years of testing, the largest average number of stems was found in the Italian ryegrass of the Draga variety (183,6 stems/plant). In all genotypes, a larger number of generative stems were determined in the first year of testing. The analysis of the variance of the average number of generative stems per plant in the investigated years show highly significant differences between the investigated genotypes. The differences between the years are significant. The variance analysis does not show the existence of an interaction effect of the genotype $\mathrm{x}$ year. During the two-year study, the lowest average number of generative stems/plant had a Tur genotype (153,5 stems/ plant), and the largest number had genotype Draga (190,8 stems/plant). The number of generative stems per plant depending on the nitrogen fertilization intensity varies from 156 to 208 (Chastain, 2000). 


\section{Average spike length}

The average length of the spikes of studied Italian ryegrass genotypes, expressed in centimetres, are given in Table 3.

Table 3. Average spike length $(\mathrm{cm})$ of studied Italian ryegrass genotypes

\begin{tabular}{|c|c|c|c|c|c|}
\hline \multirow{3}{*}{ No } & \multirow{3}{*}{\multicolumn{2}{|c|}{ Genotype (A) }} & \multicolumn{2}{|c|}{ Year (B) } & \multirow{3}{*}{$\begin{array}{l}\bar{X} \mathrm{~A} \\
(\mathrm{~cm})\end{array}$} \\
\hline & & & 2014 & 2015 & \\
\hline & & & $\bar{X} \pm S_{x}$ & $\bar{X} \pm S_{x}$ & \\
\hline 1. & \multicolumn{2}{|l|}{ Tur } & $28,8 \pm 4,2$ & $26,3 \pm 4,0$ & 27,6 \\
\hline 2. & \multicolumn{2}{|c|}{ Danergo } & $29,3 \pm 3,3$ & $27,8 \pm 4,7$ & 28,6 \\
\hline 3. & \multicolumn{2}{|c|}{ Draga } & $24,0 \pm 3,6$ & $22,8 \pm 4,3$ & 23,4 \\
\hline 4. & \multicolumn{2}{|c|}{ Tetraflorum } & $30,1 \pm 5,0$ & $28,9 \pm 4,3$ & 29,5 \\
\hline 5. & \multicolumn{2}{|c|}{ BL-Vubo } & $28,9 \pm 3,0$ & $26,4 \pm 5,3$ & 27,7 \\
\hline \multicolumn{3}{|c|}{$\bar{X} \mathrm{~B}(\mathrm{~cm})$} & 28,2 & 26,4 & \\
\hline \multicolumn{3}{|c|}{ Basic factors } & A & B & $\mathrm{AB}$ \\
\hline \multicolumn{3}{|c|}{ Variance analysis- $\mathrm{F}_{\text {calculated }}$} & $11,323^{* *}$ & $7,817^{* *}$ & 0,200 \\
\hline \multirow{2}{*}{\multicolumn{2}{|c|}{ LSD }} & 0,05 & 2,0 & 1,3 & 2,9 \\
\hline & & 0,01 & 2,7 & 1,7 & 3,9 \\
\hline
\end{tabular}

The lowest average spike length during the test is found in the Draga variety in $2015(22,8 \mathrm{~cm})$, and the largest in the Tetraflorum variety in 2014 $(30,1 \mathrm{~cm})$. The average length of the spike in variety Florida 80 was $21 \mathrm{~cm}$, variety Kowinearly $24 \mathrm{~cm}$ and variety Hwasan 101 was $34 \mathrm{~cm}$ (Choi et al., 2011). During a four-year trial (2003-2006), the average length of spikes in the Tetraflorum variety of ryegrass, grown in conditions of different inter row spacing, was from $24,1 \mathrm{~cm}$ to $35,0 \mathrm{~cm}$ (Simić et al., 2009). The average length of the spikes of investigated Italian ryegrass genotypes shows the existence of a highly significant difference between the investigated genotypes as well as between the years studied. No interaction of the genotype $x$ year has been noticed during these studies.

\section{The average number of spikelets per spike}

The results of the average number of spikelets per spike of examined genotypes of the Italian ryegrass are given in Table 4. During the two-year trials, the number of spikelets per spike was high among the tested genotypes of the Italian ryegrass, and ranged from 23,1 (Draga) to 27,1 (Tur). The smallest number of spikelets was found in the Draga variety in the second year of the testing, and the highest in the Tur variety in the first year of testing (2014). Hides et al. (1993) found an average of 24 spikelets per spike in diploid italian ryegrass. The average number of spikelets per spike during the study of several varieties of the Italian ryegrass, in the period 2003-2006 at the Suwon site in South Korea, ranged from 20 in diploid varieties up to 24 in tetraploid varieties (Choi et al., 2011). In the case of Tetraflorum variety of Italian ryegrass, during the multy-year trial conducted in the Sabac area in Serbia, the average number of spikelets per spike 
was 21,6-27,2 (Simić et al., 2009). Kovačević et al (2012) state that tetraploid variety of italian ryegrass "Mir" has 24,9-25,2 spikelets per spike.

Table 4. The average number of spikelets per spike in examined genotypes of the Italian ryegrass

\begin{tabular}{|c|c|c|c|c|c|}
\hline \multirow{3}{*}{ No } & \multirow{3}{*}{\multicolumn{2}{|c|}{ Genotype (A) }} & \multicolumn{2}{|c|}{ Year (B) } & \multirow{3}{*}{$\bar{X} A$} \\
\hline & & & 2014 & 2015 & \\
\hline & & & $\bar{X} \pm S_{x}$ & $\bar{X} \pm S_{X}$ & \\
\hline 1. & \multicolumn{2}{|l|}{ Tur } & $27,8 \pm 3,7$ & $26,3 \pm 4,0$ & 27,1 \\
\hline 2. & \multicolumn{2}{|c|}{ Danergo } & $26,8 \pm 4,7$ & $25,1 \pm 3,8$ & 26,0 \\
\hline 3. & \multicolumn{2}{|c|}{ Draga } & $23,3 \pm 3,2$ & $22,8 \pm 3,5$ & 23,1 \\
\hline 4. & \multicolumn{2}{|c|}{ Tetraflorum } & $25,8 \pm 4,6$ & $24,1 \pm 3,0$ & 25,0 \\
\hline 5. & \multicolumn{2}{|c|}{ BL-Vubo } & $27,5 \pm 3,0$ & $25,8 \pm 3,3$ & 26,7 \\
\hline \multicolumn{3}{|c|}{$\bar{X} B$} & 26,2 & 62,1 & \\
\hline \multicolumn{3}{|c|}{ Basic factors } & A & B & $\mathrm{AB}$ \\
\hline \multicolumn{3}{|c|}{ Variance analysis- $\mathrm{F}$ calculated } & $4,372^{* *}$ & $4,453^{*}$ & 0,123 \\
\hline \multirow{2}{*}{\multicolumn{2}{|c|}{ LSD }} & 0,05 & 2,2 & 1,4 & 3,2 \\
\hline & & 0,01 & 3,0 & 1,9 & 4,3 \\
\hline
\end{tabular}

An analysis of variance of the number of spikelets per spike showed a statistically highly significant difference between the investigated genotypes. The impact of the year on the number of spikelets per spike was significant.

\section{Average seed yield per plant}

The results of a two-year study of average seed yield per plant, expressed in grams, are shown in Table 5.

Table 5. Average seed yield per plant (g) in the study of the Italian ryegrass genotypes

\begin{tabular}{|c|c|c|c|c|c|}
\hline \multirow{3}{*}{ No } & \multirow{3}{*}{\multicolumn{2}{|c|}{ Genotype (A) }} & \multicolumn{2}{|c|}{ Year (B) } & \multirow{3}{*}{$\begin{array}{c}\bar{X} \text { A } \\
\text { (g) }\end{array}$} \\
\hline & & & 2014 & 2015 & \\
\hline & & & $\bar{X} \pm S_{x}$ & $\bar{X} \pm S_{X}$ & \\
\hline 1. & \multicolumn{2}{|l|}{ Tur } & $48,8 \pm 9,8$ & $37,8 \pm 8,1$ & 43,3 \\
\hline 2. & \multicolumn{2}{|c|}{ Danergo } & $59,7 \pm 10,0$ & $52,3 \pm 9,0$ & 56,0 \\
\hline 3. & \multicolumn{2}{|c|}{ Draga } & $77,4 \pm 19,3$ & $67,3 \pm 13,8$ & 72,4 \\
\hline 4. & \multicolumn{2}{|c|}{ Tetraflorum } & $52,5 \pm 10,0$ & $48,0 \pm 9,3$ & 50,3 \\
\hline 5. & \multicolumn{2}{|c|}{ BL-Vubo } & $74,0 \pm 10,1$ & $63,5 \pm 12,4$ & 68,8 \\
\hline \multicolumn{3}{|c|}{$\bar{X}$ B (g) } & 62,5 & 53,8 & \\
\hline \multicolumn{3}{|c|}{ Basic factors } & A & B & $\mathrm{AB}$ \\
\hline \multicolumn{3}{|c|}{ Variance analysis- $\mathrm{F}$ calculated } & $10,582^{* *}$ & $6,691^{*}$ & 0,130 \\
\hline \multirow{2}{*}{\multicolumn{2}{|c|}{ LSD }} & 0,05 & 10,9 & 6,9 & 15,5 \\
\hline & & 0,01 & 14,8 & 9,4 & 20,9 \\
\hline
\end{tabular}


The seed yield in the tested genotypes of the Italian ryegrass varied considerably during the year and between the years of testing. e. This is because seed loss can occur throughout the following processes: pollination, fertiliation, seed set and development, harvesting and seed cleaning (Elgersma, 1985). In the first year (2014), higher yield of seeds was achieved in all tested genotypes. During these examinations, the highest average seed yield per plant was achieved with the Draga variety (72,4 g / plant). During both years of testing, the lowest yield of seed/plant was achieved with Tur variety (Tab.5).

The analysis of variance of seed yield/plant shows the existence of statistically significant differences between the investigated genotypes. Also during the studied time, the effect of the year on seed yield of the investigated genotypes was significant. The variance analysis did not determine the existence of interaction of the genotype $\mathrm{x}$ year.

\section{CONCLUSIONS}

Based on the results of testing 5 genotypes of the Italian ryegrass in the agroecological conditions of the Banja Luka region, the following conclusions can be made:

- Meteorological conditions for the growing of the Italian ryegrass were more favourable in the first year of testing.

-During the investigation of yield and seed yield components, the new domestic variety of the Italian ryegrass "BL-Vubo", statistically, was not falling behind the most cultivated varieties in our country in any tested parameter.

-According to the number of generative stems/plant, the genotypes Draga $(183,6)$ and Danergo $(180,9)$ were noticed.

-During these tests, the highest average length of spike $(29,5 \mathrm{~cm})$ was measured in the Tetraflorum variety of Italian ryegrass.

-The highest number of spikelets per spike were determined for genotypes Tur and "BL Vubo".

-When it comes to the yield of the seed/plant, during the studied time, the genotypes Draga (72,4 g) and "BL Vubo" $(68,8 \mathrm{~g})$ were noticed..

\section{REFERENCES}

Elgersma, A. (1985): Floret site utilization in grasses: definitions, breeding perspectives and methodology. Journal of Applied Seed Production 3: 50-54.

Chastain T.G. (2000): Precipitation and grass seed yield in the Willamette valley. In: Seed Production Research, ed. W. Young, Oregon State University Ext/Crs 115, 4/01.

Choi G. J., Ji H. Ch., Kim K. Y., Park H. S., Seo S., Lee K. W., Lee S. H. (2011): Growth characteristics and productivity of cold-tolerant "Kowinearly" Italian ryegrass in the northern part of South Korea. African Journal of Biotechnology, 10(14), 2676-2682. 
Hides, D.H., C.A. Kute, A.H. Marshall (1993): Seed development and seed yield potential of Italian ryegrass (Lolium multiflorum Lam.) populations. Grass and Forage Sci. 48:181-188.

Kovačević M., Svečnjak Z., Bošnjak K., Jareš D. (2012): Effect of growth regulator and nitrogen fertilization on seed yield and germination of italian ryegrass. Sjemenarstvo, 29,3-4, 145-154.

Park B.H., Park B.S., Kang J.H. (1987): A comparison between diploid and tetraploid cultivars of Lolium multiflorum Lam, Italicum. J. Korean Grassl. Sci., 7(3), 135139.

Redfearn D.D., Venuto B.C., Pitman W.D., Alison M.W., Ward J.D. (2002): Cultivar and environment effects on annual ryegrass forage yield, yield distribution and nutritive value. Crop Sci., 42, 2049-2054.

Simić A., Vučković S., Maletić R., Sokolović D., Đorđević N. (2009): The impact of seeding rate and inter-row spacing on Italian ryegrass for seed in the first harvest yea. Turk J Agric For., 33, 425-433

Simić A., Vučković S., Ćupina B., Krstić Đ., Stanisavljević S., Milivojević M. (2010): Impact of management practices on Italian ryegrass seed quality. Journal of Agricultural Sciences, 55(2), 131-140. 